\title{
Asymptomatic bacteriuria in pregnancy and its relation to perinatal outcome
}

\author{
Anjana Verma, Smita Baheti, Medhavi Sharma*
}

Department of Obstetrics and Gynecology, GMCH, Rajasthan, India

Received: 07 October 2016

Accepted: 03 November 2016

\section{*Correspondence:}

Dr. Medhavi Sharma

E-mail: dr.medhavisharma23@gmail.com

Copyright: $\odot$ the author(s), publisher and licensee Medip Academy. This is an open-access article distributed under the terms of the Creative Commons Attribution Non-Commercial License, which permits unrestricted non-commercial use, distribution, and reproduction in any medium, provided the original work is properly cited.

\section{ABSTRACT}

Background: Asymptomatic bacteriuria is one of the cause for adverse perinatal outcome. Pregnant women are at high risk for UTIs. Women exposed to antepartum urinary tract infection had increased incidence of delivering infants with low birth weights, premature infants, preterm infants with low birth weights, than those who were not exposed. Women exposed to antepartum urinary tract infection were also more likely to experience premature labor, hypertension or preeclampsia and anemia.

Methods: Antenatal women attending Geetanjali medical college and hospital, Udaipur, OPD department were screened for asymptomatic bacteriuria and followed up till delivery. Two groups were made one with asymptomatic bacteriuria positive and treated and other with non-asymptomatic bacteriuria patients. Both groups were followed uptill delivery to note their adverse perinatal outcomes. Odds ratios (OR's) and $95 \%$ test based confidence intervals (CI's) were computed between two groups to note their perinatal and maternal outcomes.

Results: Prevalence of asymptomatic bacteriuria was $12.27 \%$. Mean gestational age at which women presented was 14-26 weeks. No incidence of pyelonephritis was found. No significant adverse perinatal outcome was noted amongst patients treated for asymptomatic bacteriuria.

Conclusions: Early screening and treatment of ASB when implemented helps in reducing adverse maternal outcome

Keywords: Asymptomatic bacteriuria, Maternal outcome, Perinatal outcome

\section{INTRODUCTION}

Asymptomatic bacteriuria is one of the cause for adverse perinatal outcome. Pregnant women are at high risk for UTIs. It begins as early as 6 weeks and is seen maximum during 22 to 24 weeks of gestation. ${ }^{1}$ Increased bladder volume and decreased bladder and ureteral tone, causes urinary stasis and ureterovesical reflux. ${ }^{1}$ Up to 70 percent of pregnant women develop glycosuria, which encourages bacterial growth in the urine. ${ }^{2}$ Significant bacteriuria has been historically defined as finding more than $10^{5}$ colony-forming units per $\mathrm{mL}$ of urine. ${ }^{2}$ Asymptomatic bacteriuria is common, with a prevalence of 10 percent during pregnancy. ${ }^{3,4}$

Untreated asymptomatic bacteriuria leads to the development of symptomatic cystitis in approximately 30 percent of patients and can lead to the development of pyelonephritis in up to $50 \%$ women. $^{6}$ Asymptomatic bacteriuria is associated with an increased risk of intrauterine growth retardation, low-birth-weight infants, prematurity, preterm labor and delivery. ${ }^{5}$

With the help of screening and treating pregnant women with asymptomatic bacteriuria, it is possible to decrease the annual incidence of pyelonephritis during pregnancy significantly. ${ }^{4,6}$ Group B streptococcal (GBS) vaginal colonization is known to be a cause of neonatal sepsis and is associated with preterm rupture of membranes, and preterm labor leading to premature delivery. In randomized controlled trials, treatment of pregnant women with asymptomatic bacteriuria has been shown to decrease the incidence of preterm birth and low-birthweight infants. ${ }^{7}$ Recurrence of UTI is around 4 to 5 
percent, pyelonephritis occurs in 2 percent of pregnant women; up to 23 percent of these women have a recurrence during the same pregnancy. ${ }^{8}$ Postpartum urologic evaluation may be necessary in patients with recurrent infections because they are more likely to have structural abnormalities of the renal system. ${ }^{8-10}$

In our previous research study "Asymptomatic bacteriuria and antibacterial susceptibility during pregnancy", ASB incidence was $12.27 \%$ and those patients were included in our study and were followed up till delivery and their perinatal outcomes were noted. ${ }^{11}$ The effect of antibiotic treatment on reducing the incidence of adverse perinatal outcome and various maternal complications of pregnancy including hypertension, preeclampsia, anaemia, amnionitis and endometritis were assessed.

\section{METHODS}

This was a prospective follow up study, which was carried out in outpatient department of Obstetrics and Gynaecology in association with Department of Microbiology, Medicine and Paediatrics in Geetanjali Medical College and Hospital, Udaipur, Rajasthan, India. A total of 220 women which were screened for asymptomatic bacteriuria during the period of 1 year from July 2013 to 2014 attending antenatal clinic at their first visit were divided into one with asymptomatic bacteriuria positive and other negative. The patients positive for asymptomatic bacteriuria were treated and all patients were followed uptil their delivery to note and analyse their perinatal and maternal outcomes. After ethical clearance from the ethical committee, informed consent was taken from all patients.

\section{Inclusion criteria}

Pregnant women attending antenatal Obstetrics and Gynaecology OPD at Geetanjali Medical College and Hospital at their first antenatal visit and were followed up till delivery to note their maternal and perinatal outcome.

\section{Exclusion criteria}

History of:

1. Urinary symptoms like frequency, urgency or dysuria.

2. Fever

3. Diabetes mellitus or Gestational diabetes

4. Renal stones or urinary tract anomalies

5. Antibiotic intake in preceding 2 weeks

A detailed history including demographic data recorded included maternal age, gravidity, parity, age of gestation, along with emphasis on past medical and obstetric history, previous antibiotic intake, previous history of urinary tract infection, personal and family history of hypertension/preeclampsia (PIH) and diabetes. Deliveries before 37 completed weeks were taken as preterm and birth weight less than $2.5 \mathrm{kgs}$ at term was regarded as low birth weight. NICU admissions were noted. Baseline investigations such as hemoglobin levels, urine-albumin and sugar, random blood sugar, blood urea, urine routine examination and urine culture and sensitivity were done.

Antibacterial susceptibility for following antibiotics were noted: Gentamicin, amikacin, cefuroxime, ceftizoxime, ceftriaxone, cefixime, amoxycilin+clavulinic acid, ampicillin, sulbactam, ciprofloxacin, levofloxacin and nitrofurantoin. Asymptomatic bacteriuria $\left(>10^{5}\right.$ colony count) were taken as positive.

Subjects with significant bacteriuria were initiated appropriate treatment by the concerned obstetrician as per their sensitivity and safety during pregnancy and followed up after one week for a repeat urine culture and sensitivity testing. Perinatal outcomes of all patients were analysed and records were noted.

The perinatal outcomes examined in this study include perinatal death (fetal death or neonatal death within the first 28 days, low birthweight (2500 $\mathrm{g}$ or lower) prematurity (less than 37 weeks gestation), preterm low birthweight $(2500 \mathrm{~g}$ or lower and less than 37 weeks gestation).

Maternal outcomes included premature labor (onset of labor prior to 37 weeks), hypertension/ preeclampsia (pregnancy-induced hypertension or preeclampsia), anemia (hematocrit less than 30\%). They were further evaluated and analysed.

Odds ratios (ORs) and $95 \%$ test based confidence intervals (CIs) were computed for exposure to antepartum urinary tract infection as well as perinatal and maternal outcomes. Mantel-Haenszel adjusted odds ratios were estimated from stratified analyses of all associations controlling for each of the potential confounders individually.

Odds ratios were calculated from beta coefficients and 95\% confidence intervals were calculated from the respective standard errors.

\section{RESULTS}

Among 220 pregnant women, 27 were found to have significant bacteriuria with a prevalence of $12.27 \%$. Among 27 patients, 11 (40.74\%) were primigravida, while $16(59.25 \%)$ were multigravida. Highest incidence of ASB (33.33\%) was reported in age group 20-25 and more than half of cases were in second trimester $(55.55 \%)$. Total 33 patients dropped out from the study (Table 1). 
Table 1: Demographic profile of women with ASB.

\begin{tabular}{|lll|}
\hline Characteristics & $\begin{array}{l}\text { Bacteriuria } \\
\text { (No.) }\end{array}$ & $\begin{array}{l}\text { No Bacteriuria } \\
(\text { No. })\end{array}$ \\
\hline Age & $1(3.70 \%)$ & $12(6.2 \%)$ \\
\hline$<\mathbf{2 0}$ & $9(33.33 \%)$ & $86(44.55 \%)$ \\
\hline $\mathbf{2 0 - 2 5}$ & $7(25.92 \%)$ & $50(25.9 \%)$ \\
\hline $\mathbf{2 6 - 3 0}$ & $5(18.51 \%)$ & $20(10.36 \%)$ \\
\hline $\mathbf{3 1 - 3 5}$ & $5(18.51 \%)$ & $25(12.95 \%)$ \\
\hline$>\mathbf{3 5}$ & 27 & 193 \\
\hline Total & & \\
\hline Trimester & $5(18.51 \%)$ & $52(26.94 \%)$ \\
\hline First & $15(55.55 \%)$ & $92(47.66 \%)$ \\
\hline Second & $7(25.92 \%)$ & $49(25.38 \%)$ \\
\hline Third & 27 & 193 \\
\hline Total & & \\
\hline Parity & $11(40.74 \%)$ & $62(32.12 \%)$ \\
\hline Nulliparous & $16(59.25 \%)$ & $131(68.22 \%)$ \\
\hline Multiparous & 27 & 193 \\
\hline Total & \\
\hline
\end{tabular}

Mean age of women presenting with features of asymptomatic bacteriuria was 20-25 years, majority women who had bacteriuria as well as who didn't had bacteriuria were multipara $16 \quad(59.25 \%)$ and 131 $(68.22 \%)$ respectively. Mean gestational age at which women presented was 14-26 weeks (Table 2). E.coli was found to be the most common pathogen affecting $59.25 \%$ of women, followed by Enterococcus (22.22\%) and Klebsiella $(7.4 \%)^{11}$

Table 2: Mean age, gestational age, and associated risk factors in relation to presence or absence of bacteriuria.

\begin{tabular}{|lll|}
\hline $\begin{array}{l}\text { Risk factors in } \\
\text { relation to presence } \\
\text { or absence of } \\
\text { bacteriuria }\end{array}$ & $\begin{array}{l}\text { Bacteriuria } \\
(\%)\end{array}$ & $\begin{array}{l}\text { No } \\
\text { bacteriuria } \\
(\%)\end{array}$ \\
\hline Age (20-25yrs.) & $9(33.33 \%)$ & $86(44.55 \%)$ \\
\hline Multiparity & $16(59.25 \%)$ & $131(68.22 \%)$ \\
\hline $\begin{array}{l}\text { Gestational age at } \\
\text { initial testing (14-26 } \\
\text { weeks) }\end{array}$ & $15(55.55 \%)$ & $92(47.66 \%)$ \\
\hline
\end{tabular}

Table 3: Perinatal outcome.

\begin{tabular}{|c|c|c|c|c|}
\hline Outcome & $\begin{array}{l}\text { Exposed } \\
(n=27)\end{array}$ & $\begin{array}{l}\text { Non-exposed } \\
(n=160)\end{array}$ & Odds ratio & $\begin{array}{l}95 \% \text { confidence } \\
\text { interval }\end{array}$ \\
\hline $\begin{array}{l}\text { Perinatal deaths } \\
\text { Yes } \\
\text { No }\end{array}$ & $\begin{array}{l}1(3.7 \%) \\
26(96.2 \%)\end{array}$ & $\begin{array}{l}1(0.62 \%) \\
159(99.5 \%)\end{array}$ & 6.115 & $0.371,100.832$ \\
\hline $\begin{array}{l}\text { Birth weight }(\mathrm{Gms}) \\
<2500 \\
>2500\end{array}$ & $\begin{array}{l}6(22.2 \%) \\
21(77.7 \%)\end{array}$ & $\begin{array}{l}11(6.8 \%) \\
149(93.11 \%)\end{array}$ & 3.870 & $1.295,11.564$ \\
\hline $\begin{array}{l}\text { Gestational age }(\mathrm{Wks}) \\
<37 \\
>37\end{array}$ & $\begin{array}{l}6(22.2 \%) \\
21(77.7 \%)\end{array}$ & $\begin{array}{l}16(10 \%) \\
144(90 \%)\end{array}$ & 2.571 & $0.905,7.304$ \\
\hline $\begin{array}{l}\text { Preterm low birth } \\
\text { Yes } \\
\text { No }\end{array}$ & $\begin{array}{l}3(11.1 \%) \\
24(88.8 \%)\end{array}$ & $\begin{array}{l}7(4.3 \%) \\
153(95.6 \%)\end{array}$ & 2.732 & $0.661,11.295$ \\
\hline
\end{tabular}

Table 4: Maternal outcome.

\begin{tabular}{|c|c|c|c|c|}
\hline Outcome & $\begin{array}{l}\text { Exposed } \\
(n=27)\end{array}$ & $\begin{array}{l}\text { Non-exposed } \\
(n=160)\end{array}$ & Odds ratio & $\begin{array}{l}95 \% \text { confidence } \\
\text { interval }\end{array}$ \\
\hline $\begin{array}{l}\text { Premature labor } \\
\text { Yes } \\
\text { No }\end{array}$ & $\begin{array}{l}6(22.2 \%) \\
21(77.7 \%)\end{array}$ & $\begin{array}{l}13(8.1 \%) \\
147(91.8 \%)\end{array}$ & 3.231 & $1.108,9.418$ \\
\hline $\begin{array}{l}\text { Hypertension } \\
\text { Yes } \\
\text { No }\end{array}$ & $\begin{array}{l}2(7.4 \%) \\
25(92.5 \%)\end{array}$ & $\begin{array}{l}5(3.1 \%) \\
145(90.629 \%)\end{array}$ & 2.480 & $0.456,13.486$ \\
\hline $\begin{array}{l}\text { Anemia } \\
\text { Yes } \\
\text { No }\end{array}$ & $\begin{array}{l}3(11.1 \%) \\
24(88.8 \%)\end{array}$ & $\begin{array}{l}7(4.5 \%) \\
153(45.6 \%)\end{array}$ & 2.732 & $0.661,11.295$ \\
\hline
\end{tabular}


Antibacterial sensitivity of nitrofurantoin against E.coli was documented $93.75 \%$, while $100 \%$ sensitivity for this antibiotic reported against enterococcus and klebseilla. $50 \%$ strains of E.coli were susceptible to cefuroxime and amoxy-clavulinic acid combination (table 3). Overall nitrofurantoin was reported to be highly sensitive (>90\%$100 \%$ ) against all strains except pseudomonas. ${ }^{11}$

Women exposed to antepartum urinary tract infection had increased incidence of delivering infants with low birthweights, premature infants, preterm infants with low birthweights, than those who were not exposed (Table 3 ). This was not statistically significant.

Women exposed to antepartum urinary tract infection had higher incidence of premature labor, hypertension/preeclampsia and anemia. Although they did not reach statistical significance (Table 4).

\section{DISCUSSION}

Incidence of asymptomatic bacteriuria in our study was $12.27 \%$. The global prevalence of bacteriuria in pregnancy varies from $4 \%$ to $23.9 \%$ in studies conducted by various authors. ${ }^{12-16}$ Incidence in studies conducted by Maryam Kasraeian et al, Vaishali et al and Ansari HQ et al among pregnant women correlates with the present study. ${ }^{15-17}$ This high prevalence is attributed to their socioeconomic status, lack of personal and environmental hygiene. There was significant association between presence of bacteriuria and certain risk factors like, low socioeconomic class, lower education level and multiparty ( $\mathrm{p}<0.05) .{ }^{[33]}$ In a study conducted by Kovavisarach $\mathrm{E}$ revealed strong association of asymptomatic bacteriuria with low education level. ${ }^{18}$ Studies conducted by Girishbabu RJ and Qudsia $\mathrm{H}$ showed multiparity as a risk factor for acquiring asymptomatic bacteriuria in pregnancy Low socio economic status also had a significant association with asymptomatic bacteriuria in pregnancy in study conducted by Goldaber $\mathrm{K}$ which showed similar association. $^{12,13,19}$

Highest incidence of ASB (33.33\%) were reported in age group 20-25 and more than half of cases were in second trimester $(55.55 \%)$ whereas in studies done by Nawal et al $(53 \%)$ and Sudha et al $(52 \%)$ majority of the women in their study belonged to the age group of 26-35 years. ${ }^{20,21}$ This high incidence of ASB in the young reproductive age group is due to early marriage and childbearing in our country, especially in the rural sector. Many studies show advancing age as a risk factor for acquiring ASB in pregnancy because there is decrease in glycogen deposition and reduction in the lactobacillus as a part of ageing process which enhances bacterial adherence and invasion by pathogens and make them more susceptible. ${ }^{21}$

In the present study, majority of the women with ASB were multigravidae $(59.25 \%)$. This was close to study done by Okonko et al. ${ }^{22}$ The higher incidence of ASB in the multigravida is due to increased colonization of urinary tract by pathogens due to repeated exposure to urinary stasis or previous infections.

In the present study antibacterial sensitivity of nitrofurantoin against E.coli was documented 93.75\%, while $100 \%$ sensitivity for this antibiotic reported against enterococcus and klebseilla. 50\% strains of E.coli were susceptible to cefuroxime and amoxy-clavulinic acid combination. Overall nitrofurantoin was reported to be highly sensitive (>90\%-100\%) against all strains except pseudomonas. Whereas Jubaida et al concluded in their study that Escherichia coli was $86.4 \%$ sensitive to Nitrofurantoin, $38.6 \%$ to Ciprofloxacin and Ceftriaxone. $^{34}$ Cephalexin was only sensitive in 4.6\% cases. Staphylococcus saprophyticus showed $75 \%$ sensitivity to Nitrofurantoin, ceftriaxone and gentamicin. $^{34}$

Escherichia coli as the most common UTI associated pathogen. $^{12,23-27,30}$ Other organisms found were Staphylococcus saprophyticus $(14.5 \%)$ and Pseudomonas species $(5.5 \%)$. The findings of the study showed that Staphylococcos saprophyticus, which was believed to be normal commensal, was recognized as the second most common pathogen accounting to $16.68 \%, 19.5 \%$ and $16.8 \%$ prevalence rate in different studies. ${ }^{28-30}$ In our study Nitrofurantoin was found to be highly sensitive to most of the isolates. This finding well correlates with the other studies carried out in Bangladesh, Pakistan and Ghana. ${ }^{24,28,31}$ Nitrofurantoin in pregnancy appeared to be safe and a survey on physicians confirmed that most practitioners adhered to recommend prescribing nitrofurantoin in pregnancy. ${ }^{7}$

In the present study no significant adverse perinatal outcome were detected in the form of preterm birth and low birth weight $(\mathrm{p}>0.05)$ none of the patient developed pyelonephritis. Similar results were found by study conducted by Shabnam Tahir et al. ${ }^{33}$ The relationship between asymptomatic bacteriuria and prematurity/low birth weight (LBW) is being into consideration by many studies but they haven't reached a conclusion yet. Metaanalysis of the relationship between asymptomatic bacteriuria and preterm delivery/low birth weight was done by Romer $\mathrm{R}$ and Oyarzun $\mathrm{E}$, to analyze and combine the results of previous studies to resolve this discrepancy among contradictory results of clinical trials. ${ }^{7,33}$ Romer R, Oyarzun E et al concluded a strong association between untreated asymptomatic bacteriuria and LBW/preterm delivery and that antibiotic treatment is effective in reducing the occurrence of $\mathrm{LBW}^{7}$ In studying the association of bacteriuria in pregnancy with poor perinatal outcome, in our study we did not find any significant difference in the incidence of preterm delivery and low birth-weight in the two groups with or without bacteriuria $(p>0.05)$. We were unable to study the effects of significant bacteriuria as we promptly treated patients after obtaining their results of antibacterial susceptibility which may have helped in improving maternal and 
perinatal outcome. Secondly, there are many other associated responsible for preterm delivery and IUGR which could influence the results.

Whereas Laura A. Schieve et al found that women who acquire urinary tract infections during pregnancy are at increased risk of delivering low birthweight, premature, and preterm low birthweight infants. ${ }^{35}$ Their odds ratios of 1.4 for low birthweight, 1.3 for prematurity, and 1.5 for preterm low birthweight compare well with a recent meta-analysis of exposure to antepartum urinary tract infection that reported typical relative risks of 1.5 and 2.0 for associations with low birthweight and prematurity, respectively. $^{36}$ An association between urinary tract infection and perinatal death was found only among the 20 - to 29-year-olds. One plausible explanation is that younger and older women are exposed to multiple risks for adverse outcomes are low socioeconomic status and other related factors among the younger age group and biological factors among the older age group-which masks the impact of urinary tract infection. ${ }^{31}$

Our analysis also shows that the associations observed between urinary tract infection and adverse perinatal outcome and maternal morbidity may be influenced by other confounding factors like age, parity and any other associated medical or obstetrical high risk factors. Antibiotics were prescribed for those correctly classified as having such an infection, indicating that the exposure group involves mainly treated cases, thereby reducing adverse maternal and perinatal outcome.

Pre-eclampsia and anemia have been associated with bacteriuria in pregnancy but we did not find any such association. In studying the association of bacteriuria in pregnancy with poor perinatal outcome, we did not find any difference in incidence of preterm delivery and low birth-weight in the two groups $(p>0.05)$ these results correlated with the study conducted by Tahir $\mathrm{S}$ et al. ${ }^{33}$ Smith $\mathrm{K}$ et al concluded that there are many factors other than bacteriuria associated with preterm delivery and low birth weight which could have influenced these results, but we were unable to study their effect as these data were excluded from their study. ${ }^{32}$

\section{CONCLUSION}

Early screening and appropriate treatment with susceptible antibiotic during antenatal period helps in reducing the incidence of pyelonephritis. No significant association was found between asymptomatic bacteriuria and perinatal and maternal complications as infections were treated and this may also be because of other confounding factors.

Further studies are needed to conclude that asymptomatic bacteriuria can lead to adverse perinatal or maternal outcomes. Thus, we conclude that early prenatal screening of women for urinary tract infection and treatment of women prevents pyelonephritis and helps in reducing adverse maternal outcomes.

Funding: No funding sources

Conflict of interest: None declared

Ethical approval: The study was approved by the Institutional Ethics Committee

\section{REFERENCES}

1. Patterson TF, Andriole VT. Bacteriuria in pregnancy. Infect Dis Clin North Am. 1987;1:807-22.

2. Stamm WE, Hooton TM. Management of urinary tract infections in adults. $\mathrm{N}$ Engl $\mathrm{J}$ Med. 1993;329:1328-34.

3. Kass EH. Pregnancy, pyelonephritis and prematurity. Clin Obstet Gynecol. 1970;13:239-54.

4. Gratacos E, Torres PJ, Vila J, Alonso PL, Cararach V. Screening and treatment of asymptomatic bacteriuria in pregnancy prevent pyelonephritis. J Infect Dis. 1994;169:1390-2.

5. Harris RE, Thomas VL, Shelokov A. Asymptomatic bacteriuria in pregnancy: antibody-coated bacteria, renal function, and intrauterine growth retardation. Am J Obstet Gynecol. 1976;126:20-5.

6. Harris RE. The significance of eradication of bacteriuria during pregnancy. Obstet Gynecol. 1979;53:71-3.

7. Romero R, Oyarzun E, Mazor M, Sirtori M, Hobbins JC, Bracken M. Meta-analysis of the relationship between asymptomatic bacteriuria and preterm delivery/low birth weight. Obstet Gynecol. 1989;73:576-82.

8. Gilstrap LC 3d, Cunningham FG, Whalley PJ. Acute pyelonephritis in pregnancy: an anterospective study. Obstet Gynecol 1981;57:409-13.

9. Loughlin KR. Management of urologic problems during pregnancy. Urology. 1994;44:159-69

10. Diokno AC, Compton A, Seski J, Vinson R. Urologic evaluation of urinary tract infection in pregnancy. J Reprod Med. 1986;31:23-6.

11. Verma A, Vyas A, Shrimali L, Sharma M. Asymptomatic bacteriuria and antibacterial susceptibility during pregnancy. Int $\mathrm{J}$ Reprod Contracept Obstet Gynecol. 2016;5(2):407-10.

12. Girishbabu RJ. Asymptomatic bacteriuria in pregnancy. Int J Biol Med Res. 2011;2(3):740-2.

13. Qudsia H. Prevalance of asymptomatic bacteruria and associated risk factors among antenatal women attending a tertiary care hospital. J Med Allied Sci. 2011;1(2):74-8.

14. Mackejko AM, Schaeefer AJ. Asymptomatic bacteriuria and symptomatic urinary tract infection during pregnancy. Urological clinics Of North America. 2007 ;34(1):35-47.

15. Kasraeian M. Prevalence of asymptomatic bactetiuria among pregnant women in Shiraz, Iran. Saudi Med J. 2009;30(7):917-20.

16. Ansari HQF, Rajkumari A. Prevalence of asymptomatic bacteriuria and associated risk factors 
among antenatal women attending a tertiary care hospital. J Med Allied Sci. 2001;1(2):74-8.

17. Jain V, Das V, Agarwal A, Pandey A. Asymptomatic bacteriuria and obstetric outcome following treatment in early versus late pregnancy in north Indian women. The Indian Journal of Medical Research. 2013;137(4):753.

18. Kovavisarach E,Vichaipruck M, Risk factors related to asymptomatic bacteriuria in pregnant women. J Med Assoc Thai. 2009;92(5):606-10.

19. Goldaber K. Urinary tract infection during pregnancy. Infect Urol. 1997;10:152-7 .

20. Al Senani NS. Asymptomatic bacteriuria in pregnant women. Bahrain Med Bull. 2011;33:1-4.

21. Sudha Biradar K, Rajeshwari S, Sheela S Sagarad, Sneha Hegadi. Asymptomatic bacteriuria among pregnant women. Int $\mathbf{J}$ Reprod Contracept Obstet Gynecol. 2013;2(2):213-6.

22. Okonko IO, Ijandipe LA, Ilusanya AO, DonbrayeEmmanuel OB. Detection of Urinary Tract Infection (UTI) among pregnant women in Oluyoro Catholic Hospital, Ibadan, South-Western Nigeria. Malaysian Journal of Microbiology. 2010;6(1):16-24.

23. Hazhir S. Asymptomatic bacteriuria in pregnant women. Urol J (Tehran). 2007;4:24-7.

24. Selimuzzaman ABM. Asymptomatic bacteriuria during pregnancy: Causative agents and their sensitivity in Rajshahi city. The Journal of Teachers association RMC, Rajshahi. 2006;19(2):66-9.

25. Ahmed S. Prevalence of asymptomatic bacteriuria among pregnant women in Kashmir. Sri Lanka Journal of obstetrics and gynaecology. 2011;33:15862.

26. Anayet Ullah M. Prevalence of asymptomatic bacteriuria and its consequences in pregnancy in a rural community of Bangladesh. Bangladesh Med Res Counc Bull. 2007;33:60-4.

27. Enayat K. Asymptomatic bacteriuria amongpregnant women referred to outpatient clinics in Sanandaj, Iran. International Braz J Urol. 2008;34(6):699-707.
28. Khattak AM. Antimicrobial sensitivity pattern of urine isolates from asymptomatic bacteriura during pregnancy. E:/Biomedica. 2006;22.

29. Turpin CA. Asymptomatic bacteriuria in pregnant women attending antenatal clinic at Komfo Anokye teaching hospital, Kumasi, Ghana. Ghana Medical Journal. 2007;41(1):26-9.

30. Sheiner E. Asymptomatic bacteriuria during pregnancy. The Journal of Maternal-Fetal and Neonatal Medicine. 2009;22(5):423-7.

31. Institute of Medicine. Preventing Low Birthweight. Washington, DC: National Academy Press; 1985:4693.

32. Kincaid-Smith $P$, Bullen $M$. Bacteriuria in pregnancy. Lancet. 1965;1:395-99.

33. Tahir S. Prevalence of Asymptomatic Bacteriuria, Associated Risk Factors and Adverse Fetomaternal Outcome among Antenatal women attending a tertiary care hospital. Department of Gynae Obs, Shalamar Teaching Hospital, Lahore. 2015;9(4):1399-402.

34. Jubaida N, Kawsar NM, Elora N, Rahimgir M, Shapla NR, Al-muid Sma. Prevalence of asymptomatic bacteriuria in pregnant women. JAFMC Bangladesh. 213;9(2).

35. Schieve LA, Handler A. Urinary Tract Infection during pregnancy: Its Association with Maternal Morbidity and Perinatal Outcome.American Journal of Public Health. 1994;84:405-10.

36. Romero R, Oyarzun E, Mazor M, Sirtori M, Hobbins JC, Bracken M. Metaanalysis of the relationship between asymptomatic bacteriuria and preterm delivery/low birth weight. Obstet Gynecol. 1989;73:576-82.

Cite this article as: Verma A, Baheti S, Sharma M.

Asymptomatic bacteriuria in pregnancy and its relation to perinatal outcome. Int J Reprod Contracept Obstet Gynecol 2016;5:4390-6. 


\section{Proforma}

Prospective analysis of perinatal outcome of pregnant women with asymptomatic bacteriuria

NAME W/O

Age religion

Address registration no.

\section{LMP EDD}

Complaints of:

Obstetric History:

Trimester wise asymptomatic bacteriuria diagnosed and treated:

First trimester

Second trimester

Third trimester

Mode of delivery: DOD: Baby weight: Sex: APGAR Score:

\begin{tabular}{|ll|}
\hline Maternal complications & Perinatal complications \\
\hline Preterm delivery & LBW $(<2.5 \mathrm{kgs})$ \\
\hline Pyelonephritis & Prematurity $(<37$ weeks $)$ \\
Fever & \\
Flank pain & \\
\hline Hypertension/Pre-ecclampsia & Preterm LBW \\
\hline Anaemia & Neonatal Jaundice \\
\hline Amnionitis & Respiratory Distress Syndrome \\
\hline
\end{tabular}

\section{Routine investigations}

- CBC - S.TSH - Blood Sugar - HIV - HBsAg

- Urine routine - Urine culture and sensitivity 